\title{
Geospatial Assessment of Crime and Security in Ido Local Government Area, Oyo State, SouthWest Nigeria
}

\author{
Babatunde Akeem Adesola*, Oyekola Martins Adewale \\ Department of Surveying and Geoinformatics, Faculty of Environmental Studies, The Polytechnic Ibadan, Ibadan, Nigeria \\ Email address: \\ bakeem44@yahoo.com (B. A. Adesola) \\ ${ }^{*}$ Corresponding author \\ To cite this article: \\ Babatunde Akeem Adesola, Oyekola Martins Adewale. Geospatial Assessment of Crime and Security in Ido Local Government Area, Oyo \\ State, SouthWest Nigeria. International Journal of Environmental Protection and Policy. Vol. 7, No. 2, 2019, pp. 46-60. \\ doi: $10.11648 /$ j.ijepp.20190702.12
}

Received: March 5, 2019; Accepted: April 10, 2019; Published: May 6, 2019

\begin{abstract}
Utilization of Information Technology is required in public safety management in the cities and their suburb such as the present Ido area, Ido local government Ibadan. Geographic Information System (GIS) is an important tool that can be used to locate crime area, and thus allow police to proactively respond to the situations before constituting a problem. This research investigates crime and security in Ido Local Government Area of Oyo State, Southwest Nigeria with the aim of mapping and assessing the area prone to crime, leading causes. The methodology adopted in this research was field surveying methods with the use of Hi-target differential GPS to acquire the spatial coordinate $(x, y, z)$ of crime hotspots/locations and police stations in the study area. The local government consists of five areas namely; Omi-Adio with seven (7) communities, Ologuneru with eight (8) communities, Ido with thirteen (13) communities, Apete with fifteen (15) communities and Apata division with eleven (11) communities. The data acquired through field surveying measurement with the Hi-target differential GPS was processed with Hi-target Geomatics Office (HGO) and Global Navigation Satellite System (GNSS) application software in order to acquire the spatial location $\mathrm{x}, \mathrm{y}, \mathrm{z}$ data of the crime hotspots and police stations. Proximity of police stations to crime hotspots was calculated to know how each of the crime hotspot was distant to the police station. Further processing was done with the use of Quick Bird satellite imagery, ArcGIS 10.2.1 (Arcmap 10.2.1) GIS application software in analyzing the location of crime and also identification of crime patterns. The result from the crime data obtained from the field measurement and police was presented in form of charts and map/plan. Generally from the research, it can be concluded that the major crime types common in the study area. Therefore, the security issues in Ido local government has been dealt with but still requires more attentions by the government and the law enforcement agencies.
\end{abstract}

Keywords: Geographic Information System (GIS), Crime Hotspots, Police Proximity

\section{Introduction}

Crime can be defined as a culpable disposition of an individual or group as entrenched in the constitution of a state. It is an act of commission or omission with legal criminal implication for which punishment must be served by an individual or group found culpable by a competent court of jurisdiction. Crime is an unlawful act that is punishable by the state law or other statutes. It is an act done by person/group of people which is against the law of a state, country or region. Crime mapping is the use of
Geographic Information System (GIS) to visualize and organize spatial data for more formal statistical analysis. Spatial analysis can be employed in both an exploratory and well as a more confirmatory manner with the primary purpose of identifying how certain community or ecological factors (such as population characteristics or the built environment) influence the spatial patterns of crime. Crime mapping can also be used to visualize and analyze the movement or target selection patterns of criminals. GIS 
helps crime officers determine potential crime sites by examining complex seemingly unrelated criteria and displaying them all in a graphical, layered, spatial interface or map. The location of a crime is an important attribute feature, and is included along with law, offender, and target as a dimension of a criminal event [1]. Crime is a 'deviant behaviour that violates prevailing norms, which may be cultural, social, political, psychological and economic conditions' [2]. [3] cited by [4], described crime as a deviant act that is threatening moral behaviours and injurious to society. Moral decadence afflicts the personality of individual, his property and lessens trust among members of the society which may result to threat and fear. Crime as violation of 'property rights' where the focus was prioritized on crime against property [5]. This will not give a comprehensive understanding on crime; hence there are many other areas where crimes are committed. Crime as an act that violates the law of the society or serious offence against the law of the society for which there is a severe punishment by law as expressed by [2]. Many researchers classified crime into violent and property crimes [5-7, 4, 8-13]. This classification is on the basis of entity on which crime is committed. Violent crime as a criminal activity that is clearly an act of brute force engaged in taking of property or a person's life [4]. Similarly Dambazau [10] in his explanation on violent crime said that it is an act of forcible taking of property from a victim and may cause injury or loss of life. Violent crime is the most 'inhumane' crime that continues to plague the societies that have taken the centre stage leading to bloodshed and economic setbacks as noted by [8].

Unemployment and economic hardship have pushed many 'jobless youths, some of whom are graduates, into various deadly crimes' as opined by [8]. Unemployment is the main causes for 'eruption and escalation of crimes in urban areas across the breadth of Nigeria' as found by [14]. Unemployment is closely linked to crime no matter the region of the World. He also argued that urban crimes are influenced by poverty, unstable jobs, the high cost of living and financial difficulties, limited educational opportunities, inadequate health and sanitation, and inadequate housing as posits by [13]. Unemployment, poverty, poor governance and lack of policy initiatives and implementation to some extent encouraged criminal groups to thrive and appear to be the root cause of urban crimes as believed by [8]. Therefore, urbanization does not have an exclusive hold on urban crime causes but, [13] concludes that it does increase the opportunities to be exposed to criminal activities. Therefore, this study aimed at mapping the crime hotspots and determining police station proximity to crime each crime area in Ido local government area, Oyo State, Southwest, Nigeria.

\section{The Study Area}

The study area is Ido local government area, Oyo State, Southwest Nigeria. The local government consists of five divisional area with communities under them. The total population of Ido local government according to the 2006 population census was 103,261 [15]. It lies between longitude $3^{\circ} 47^{\prime} 34.99^{\prime \prime} \mathrm{E}$ and latitude $7^{\circ} 30^{\prime} 44.49^{\prime \prime} \mathrm{N}$. Table 1 described the division areas and place under the study location

Table 1. Places under the five divisions in the study area are the following.

\begin{tabular}{|c|c|c|c|c|c|}
\hline S/No. & Omi-Adio & Ologuneru & Ido & Apete & Apata \\
\hline 1 & Aba Teacher & Ajadi & Alako & Adaba & BCJ \\
\hline 2 & Abidogun & Alafara & Dada & Arokoto & Bode-Igbo \\
\hline 3 & Bakatari & Gbopa & Esaru 1 & Awotan & Command \\
\hline 4 & Eleso & Olonde & Gbingbin & Fanawole 2 & Dogo \\
\hline 5 & Gate & Adetokun & Idi-Amu & Fanawole 1 & Fatimoh \\
\hline 6 & Omi & Elenusonso & Ido & Jeje & Gada/Odo-Ona \\
\hline 7 & Oke Oloro & Akatapa & Koguo & Oju Oja 1 & Idi-Iroko \\
\hline 8 & - & Temidayo & Idiiroko & Oju Oja 2 & Ile-Epo Apata \\
\hline 9 & - & - & Iloka & Oju Oja 3 & Owode 1 \\
\hline 10 & - & - & Tade & Trailer Park & Owode 2 \\
\hline 11 & - & - & Iletuntun & Arola & Wire \& Cable \\
\hline 12 & - & - & Ode Imu & Yidi & - \\
\hline 13 & - & - & Idiiko & Akodu & - \\
\hline 14 & - & - & - & Ariyibi & - \\
\hline 15 & - & - & - & Okeodan & - \\
\hline
\end{tabular}




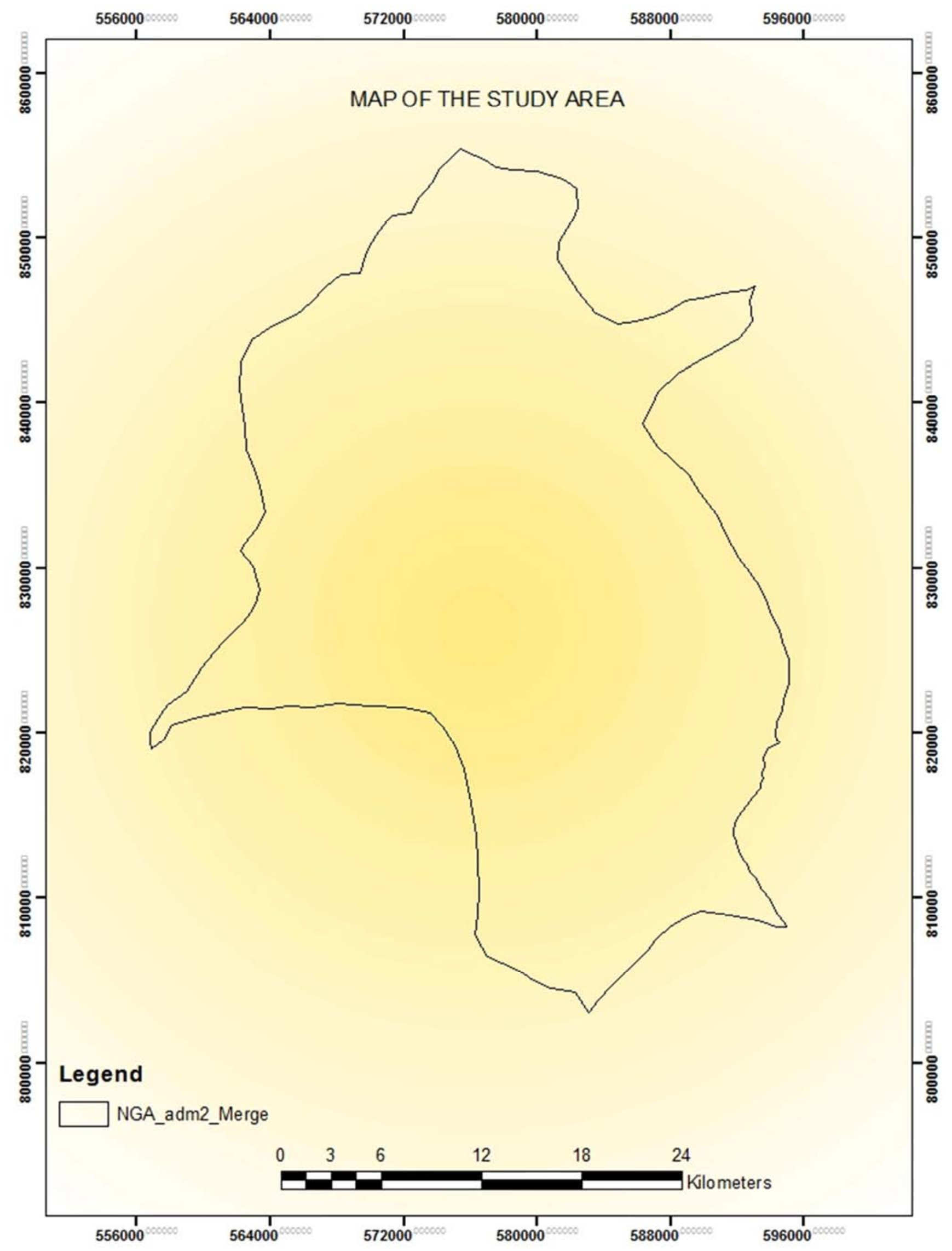

Figure 1. Digitized Map of the Study Area. 


\section{Material and Methods}

For the purpose of this research, the main source of data was adopted from field observations through surveying method as primary data. The primary data source was based on the use of Hi-target differential Global Positioning System to acquire the $(\mathrm{x}, \mathrm{y}, \mathrm{z})$ coordinates of crime hotspots for mapping purposes. Secondly, the secondary data source was adopted from the $\mathrm{x}, \mathrm{y}$, $\mathrm{z}$, coordinate collected from the Oyo State Secretariat Agodi Ibadan, Journals, Books, Conference paper presentation and the information of number of police officers/staff from the police divisional headquarter in the study area.

\subsection{Equipment Used}

\subsubsection{Hardware}

i. Hi-target Differential Global Positioning System with its accessories (Model V30 GT)

ii. Handheld Global Positioning System (78s) for ground tuiting

iii. Laptop computer (Dell Version)

iv. Hp laserjet printer (2015 version)

v. Safety boot (5 pairs)

vi. Raincoat/water proof jacket (5)

\subsubsection{Software}
i. Quickbird satellite image
ii. ArcGIS 10.2.1 (Arcmap 10.2.1)
iii. Microsoft word office 2007
iv. Microsoft Excel 2007

\subsection{Method/Procedures of Data Acquisition}

\subsubsection{Procedures of Acquiring Data for Crime Hotspots}

Hi-target differential GPS which comprises of two GPS (one at control station called base station and the other one on all point to determine called the rover station) was used to acquire the coordinate $\mathrm{x}, \mathrm{y}, \mathrm{z}$ of crime hotspots in the study area. The mode of operation used in acquiring the data was static mode whereby the differential GPS on the base station acquire a single data and continue to refine it to the maximum accuracy while the other GPS which serve as rover in all crime hotspots to be determined was given a time interval of five (5) minutes to acquire $(x, y, z)$ data for all the hotspots in the study area. The field observation commenced from a known control point at Eleyele hill with control number (ICS 147 P) (table 2). One of the GPS was set on the control point which serves as base station and the other one was used as a rover on all crime hotspots. The spatial locations of the five police division areas were also acquired using the same method (table 3). Table 4 showed number of staff per police station.

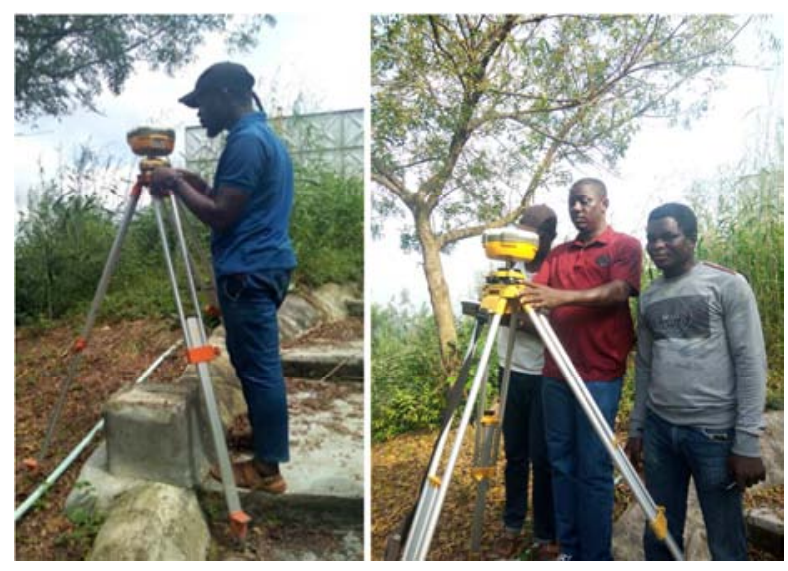

Figure 2. Data Acquisition on Control Point (base point) at Eleyele Hill.

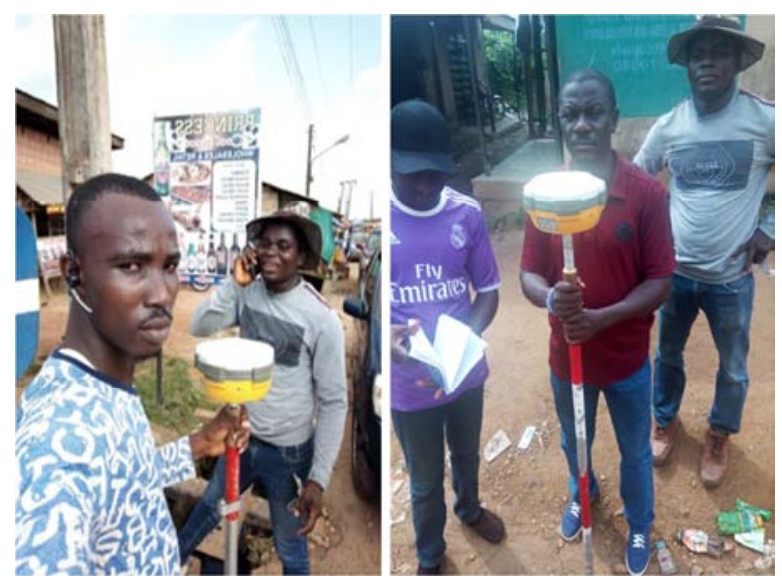

Figure 3. Data Acquisition on crime area.

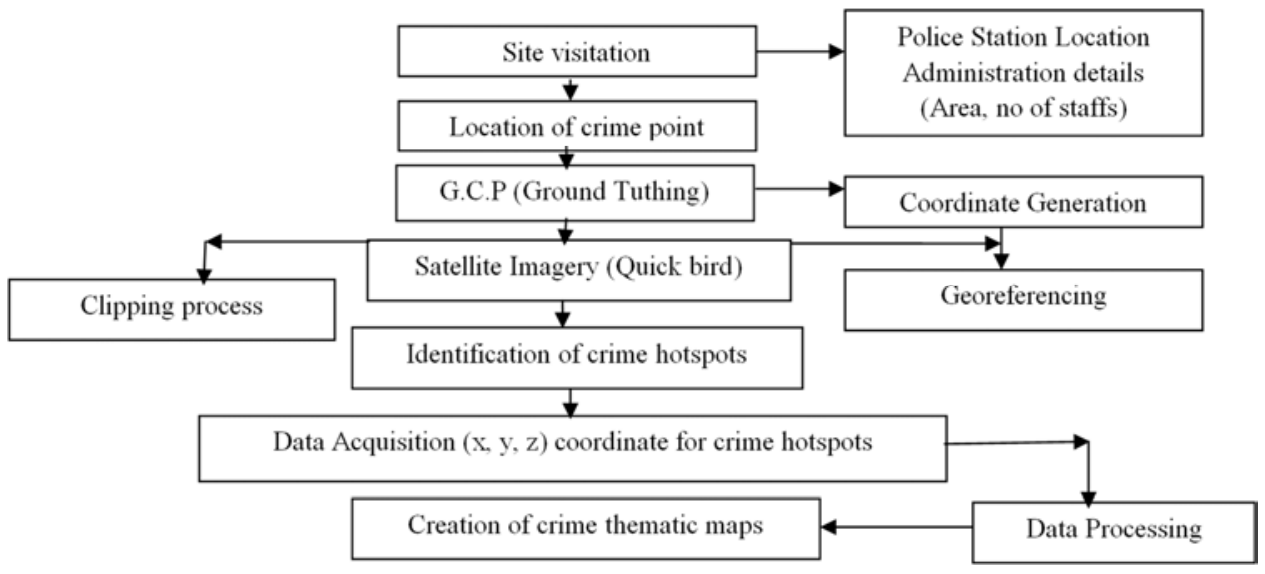

Figure 4. Methodology workflow/framework for the research. 
Table 2. Coordinate of control point collected from Oyo State Secretariat.

\begin{tabular}{llll}
\hline Control Point & Easting (m) & Northing (m) & Height (m) \\
\hline ICP 147 P & 594068.598 & 820087.878 & 257.921 \\
\hline
\end{tabular}

\section{Data processing}

The data acquired with the Hi-target differential GPS was downloaded into the computer. Hi-target Geomatics Office (HGO) and Global Navigation Satellite System (GNSS) application software was used to process the data $\mathrm{x}, \mathrm{y}, \mathrm{z}$ acquired from the field (see figures 5-7 for processing detail for the result of the processed data). The processed data $x, y$, $\mathrm{z}$ were presented from (table 5). Distance from each police division area to the crime hotspots was calculated to know how far each of the crime hotspots is distant to the police station (table 6).

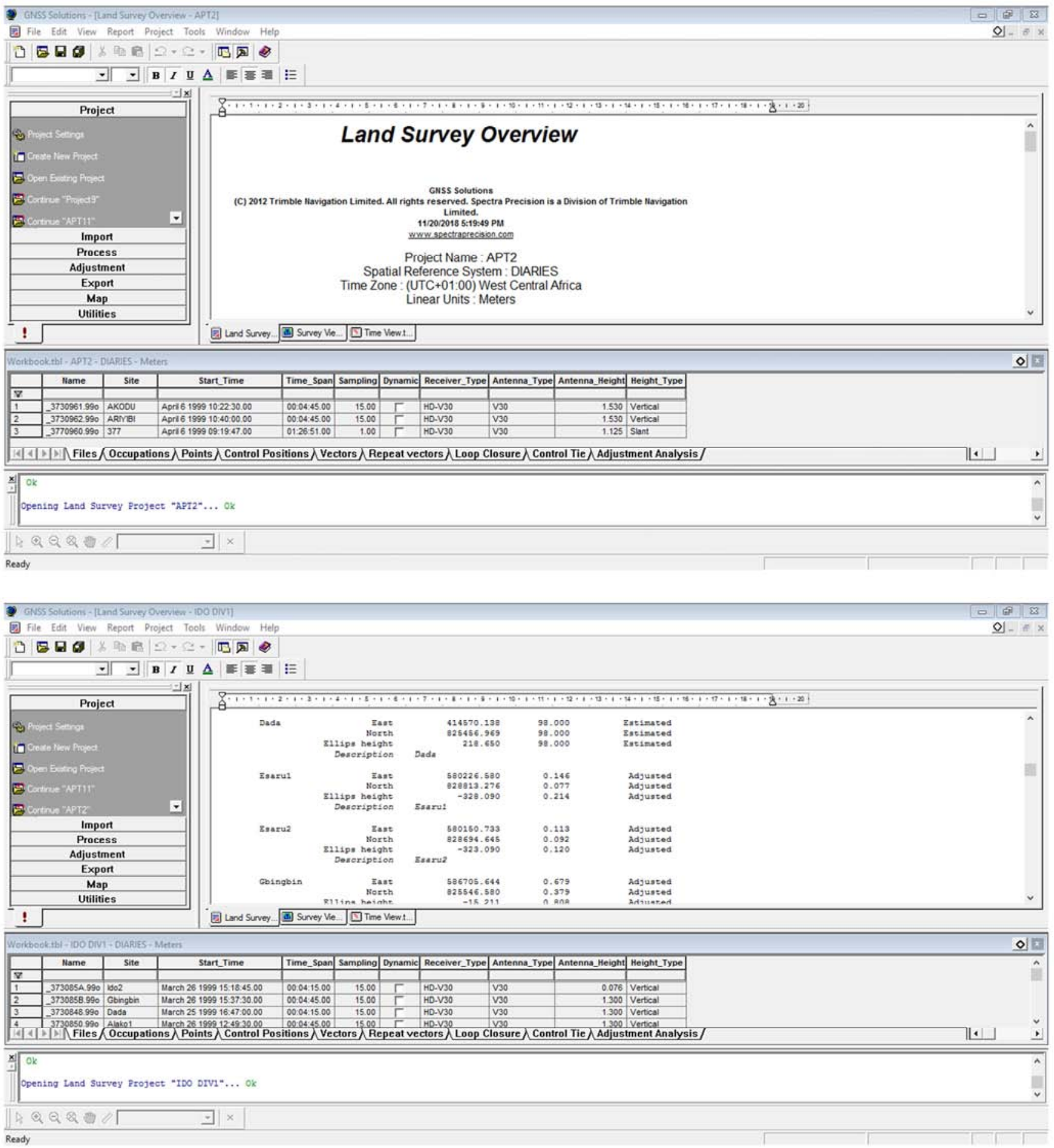

Figure 5. GNSS data under process for the $x, y, z$. 


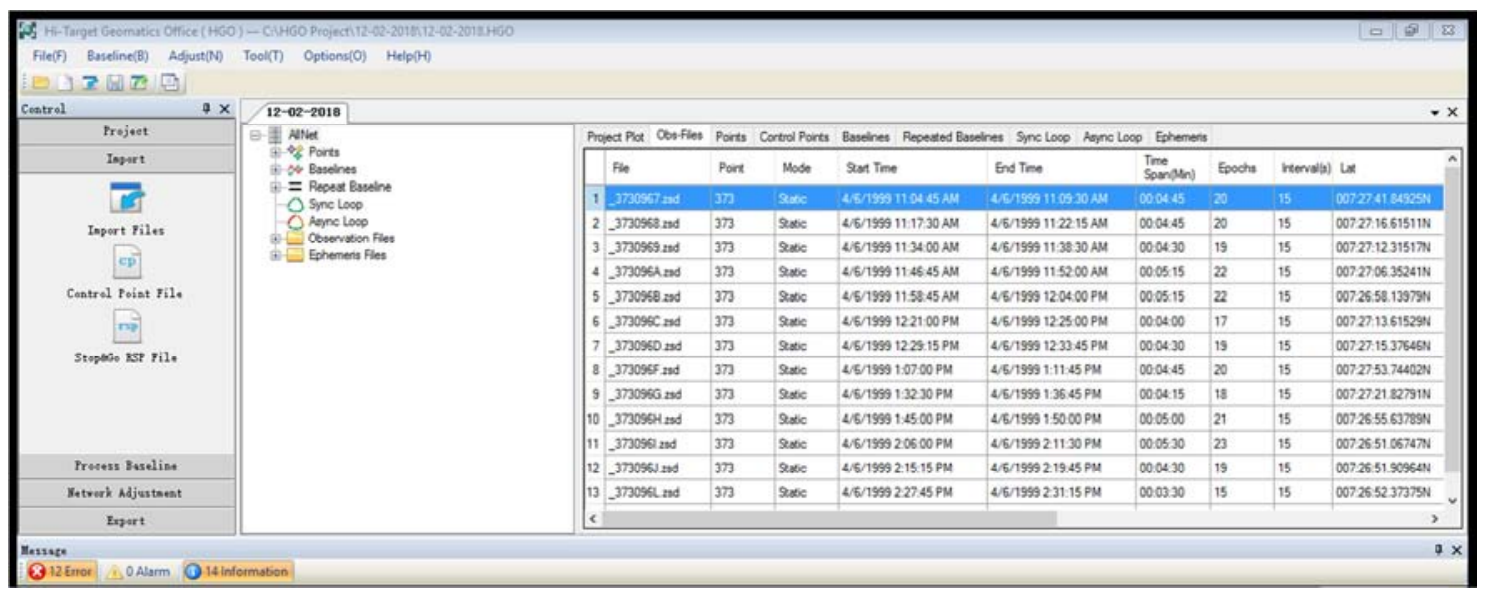

Fid Hi-Target Geomatics Office ( HGO ) - CiHGO ProjectMr. Akeem GNSSMMr. Akeem GNSS.HGO

미이 23

File(F) Baseline(B) Adj
$\square \square \mathbb{Z} \square \square$

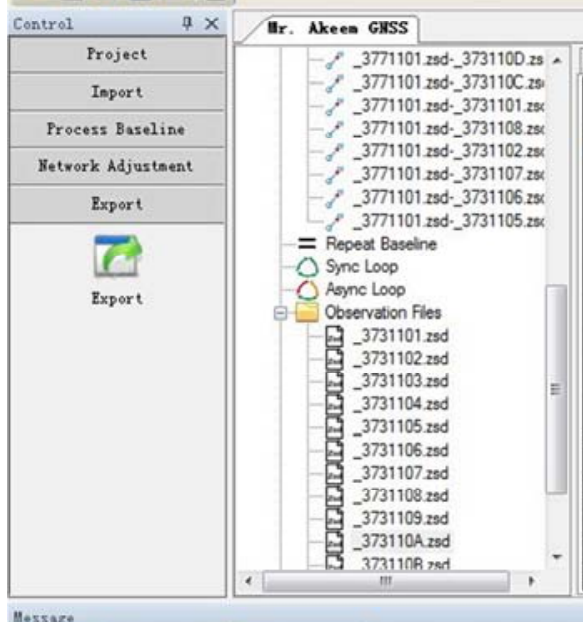

Ir. Akeea GISS

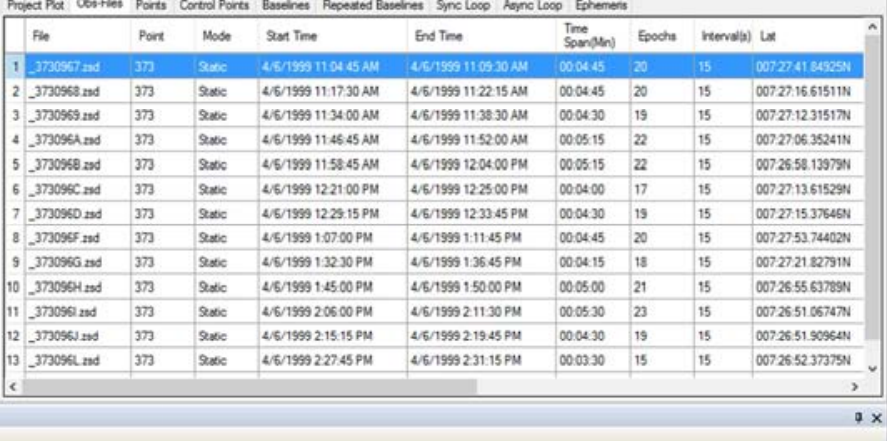

(8) Error $\triangle 0$ Alarm 0 information

\section{Details}

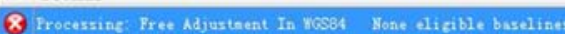

Figure 6. Showing HGO data processing for the $x, y, z$.

Fis Hi-Target Geomatics Office (HGO) - C:HGO ProjectMr. Akeem GNSSIMr. Akeem GNSS.HGO

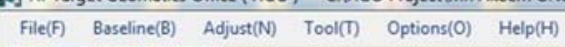

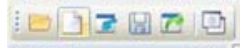

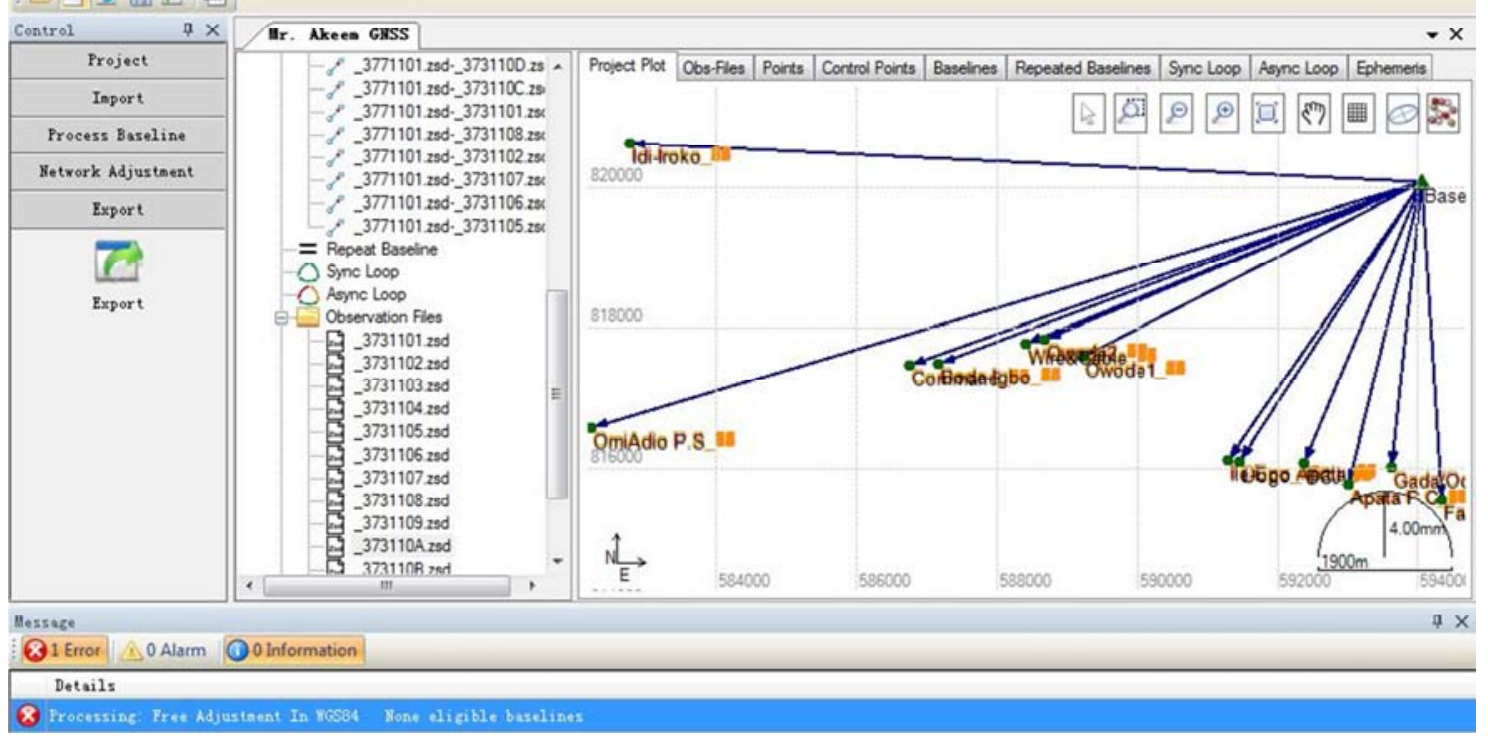

Figure 7. Showing HGO data processing showing crime locations. 
Table 3. Number of police officer present in each of the five division area.

\begin{tabular}{llll}
\hline Location & Male & Female & Total \\
\hline Omi-Adio & 40 & 28 & 68 \\
Ologuneru & 6 & 4 & 10 \\
Ido & 47 & 23 & 70 \\
Apete & 30 & 23 & 53 \\
Apata & 40 & 15 & 65 \\
Total & 163 & 93 & 266 \\
\hline
\end{tabular}

The Source of the table 3 above is from Oyo State Police Command and the information was collected in November, 2018.

Table 4. Processed coordinates $x, y, z$ of the police station.

\begin{tabular}{llll}
\hline Police Station Location & Easting (m) & $\begin{array}{l}\text { Northing } \\
(\mathbf{m})\end{array}$ & Height (m) \\
\hline Omi-Adio Police Station & 582234.713 & 816564.773 & 280.904 \\
Ologuneru Police Station & 591685.710 & 821872.890 & 217.233 \\
Ido Police Station & 584111.510 & 825947.850 & 212.089 \\
Apete Police Station & 596236.120 & 823526.710 & 185.466 \\
Apata Police Division & 593012.171 & 815752.642 & 269.053 \\
\hline
\end{tabular}

Table 5. Processed data (x, y, z) coordinates of crime hotspots in five Division areas.

\begin{tabular}{|c|c|c|c|}
\hline Location & Easting (m) & Northing (m) & Height (m) \\
\hline \multicolumn{4}{|c|}{ Omi-Adio Division } \\
\hline Aba Teacher & 582267.188 & 816565.680 & 240.101 \\
\hline Abidogun 1 & 582895.511 & 817017.921 & 183.965 \\
\hline Bakatari 1 & 577118.612 & 817240.636 & 397.64 \\
\hline Eleso & 578497.342 & 817376.080 & 338.871 \\
\hline Gate & 582642.469 & 817092.339 & 223.597 \\
\hline Omi & 582681.321 & 817003.459 & 194.829 \\
\hline Oke Oloro & 583113.182 & 816817.829 & 215.652 \\
\hline \multicolumn{4}{|c|}{ Ologuneru Division } \\
\hline Ajadi & 592343.515 & 821368.325 & 162.219 \\
\hline Alafara & 591341.963 & 820721.985 & 111.434 \\
\hline Gbopa & 590457.805 & 822606.910 & 111.479 \\
\hline Olonde & 590971.621 & 823301.405 & 137.727 \\
\hline Adetokun & 592978.551 & 820507.383 & 172.053 \\
\hline Temidayo & 579883.140 & 829049.200 & 156.345 \\
\hline Akatapa & 589758.237 & 826827.444 & 180.225 \\
\hline Elenusonso & 591256.575 & 822144.706 & 122.564 \\
\hline \multicolumn{4}{|l|}{ Ido Division } \\
\hline Alako & 575800.594 & 832637.066 & 483.389 \\
\hline Dada & 583057.103 & 823279.392 & 134.076 \\
\hline Esaru & 580226.558 & 828813.276 & 328.09 \\
\hline Gbingbin & 586705.644 & 825546.580 & 15.211 \\
\hline Idi-Amu & 577254.284 & 830998.218 & 485.333 \\
\hline Idiiroko & 582779.606 & 820630.038 & 280.022 \\
\hline Ido & 583373.904 & 825699.938 & 106.372 \\
\hline Koguo & 579619.457 & 829773.699 & 335.205 \\
\hline Ile Titun & 583116.066 & 828718.336 & 298.560 \\
\hline Idiiko & 577770.811 & 821769.041 & 215.269 \\
\hline Tade & 580988.151 & 822271.750 & 308.117 \\
\hline Ode Imu & 575609.185 & 824493.946 & 255.416 \\
\hline Iloka & 577783.488 & 827963.578 & 200.055 \\
\hline \multicolumn{4}{|c|}{ Apete Division } \\
\hline Adaba & 593915.448 & 824161.877 & 199.225 \\
\hline Arokoto & 595271.379 & 823969.821 & 264.853 \\
\hline Awotan & 595170.340 & 823366.951 & 242.113 \\
\hline Fanawole 2 & 596459.322 & 823703.878 & 269.459 \\
\hline Fanawole 1 & 596222.883 & 823886.849 & 262.927 \\
\hline Jeje & 595376.538 & 823914.256 & 263.92 \\
\hline Oju Oja 1 & 596634.688 & 823236.537 & 267.64 \\
\hline Oju Oja 2 & 596573.916 & 823266.439 & 265.368 \\
\hline Oju Oja 3 & 596753.991 & 823278.970 & 268.017 \\
\hline
\end{tabular}

\begin{tabular}{llll}
\hline Location & Easting $(\mathbf{m})$ & Northing $(\mathbf{m})$ & Height $(\mathbf{m})$ \\
\hline Trailer Park & 593175.697 & 825137.709 & 172.077 \\
Arola & 596487.271 & 824023.054 & 268.124 \\
Yidi & 596164.684 & 824799.794 & 267.178 \\
Akodu & 595423.965 & 825524.314 & 264.595 \\
Ariyibi & 595195.186 & 825481.432 & 249.491 \\
Oke Odan & 595212.620 & 826625.440 & 242.003 \\
Apata Division & & & \\
BCJ & 592384.629 & 816060.785 & 288.536 \\
Bode-Igbo & 587182.258 & 817473.872 & 294.281 \\
Command & 586763.548 & 817456.613 & 299.148 \\
Dogo & 591474.114 & 816095.427 & 297.870 \\
Fatimoh & 594346.151 & 815531.562 & 270.721 \\
Gada/Odo-Ona & 593627.664 & 816012.915 & 261.344 \\
Ile-Epo Apata & 591305.647 & 816112.294 & 293.855 \\
Owode 1 & 589242.748 & 817581.588 & 308.413 \\
Owode 2 & 588696.688 & 817826.584 & 314.295 \\
Wire\&Cable & 588420.990 & 817770.302 & 313.781 \\
\hline
\end{tabular}

Table 6. Distance/proximity of Police Station to Crime Area.

\begin{tabular}{|c|c|c|}
\hline $\begin{array}{l}\text { Police } \\
\text { Station } \\
\end{array}$ & $\begin{array}{l}\text { Crime location } \\
\text { hotspots }\end{array}$ & $\begin{array}{l}\text { Distance from Police Station } \\
\text { to crime area in } \mathbf{k m}\end{array}$ \\
\hline \multirow{7}{*}{ Omi } & Aba Teacher & 0.18 \\
\hline & Abidogun & 0.82 \\
\hline & Bakatari & 5.06 \\
\hline & Eleso & 3.71 \\
\hline & Gate & 0.63 \\
\hline & Omi & 0.62 \\
\hline & Oke Oloro & 0.91 \\
\hline \multirow{8}{*}{ Ologuneru } & Ajadi & 0.88 \\
\hline & Alafara & 1.31 \\
\hline & Gbopa & 1.41 \\
\hline & Olonde & 1.53 \\
\hline & Adetokun & 1.93 \\
\hline & Akatapa & 0.54 \\
\hline & Elenusonso & 0.51 \\
\hline & Temidayo & 3.89 \\
\hline \multirow{15}{*}{ Apete } & Adaba & 2.41 \\
\hline & Arokoto & 1.06 \\
\hline & Awotan & 1.07 \\
\hline & Fanawole 2 & 0.37 \\
\hline & Fanawole 1 & 0.29 \\
\hline & Jeje & 0.94 \\
\hline & Oju Oja 1 & 0.49 \\
\hline & Oju Oja 2 & 0.42 \\
\hline & Oju Oja 3 & 0.57 \\
\hline & Trailer Park & 3.46 \\
\hline & Arola & 1.75 \\
\hline & Yidi & 1.39 \\
\hline & Akodu & 2.14 \\
\hline & Ariyibi & 2.31 \\
\hline & Okeodan & 3.29 \\
\hline \multirow{13}{*}{ Ido } & Alako & 10.68 \\
\hline & Dada & 2.87 \\
\hline & Esaru & 4.84 \\
\hline & Gbingbin & 2.61 \\
\hline & Idi-Amu & 8.53 \\
\hline & Ido & 0.79 \\
\hline & Koguo & 5.91 \\
\hline & Idi-Iroko & 5.48 \\
\hline & Ile-titun & 2.93 \\
\hline & Idiiko & 7.60 \\
\hline & Tade & 4.83 \\
\hline & Ode Inu & 8.64 \\
\hline & Iloka & 6.65 \\
\hline
\end{tabular}




\section{Results, Analysis and Discussion}

The result presented in figures 8-19 was as a result of field observations on crime hotspots and police station locations through the field observations by surveying method. The result showed generalized map of crime hotspots and police station, the individual area showing communities where crime occurred in the study area.

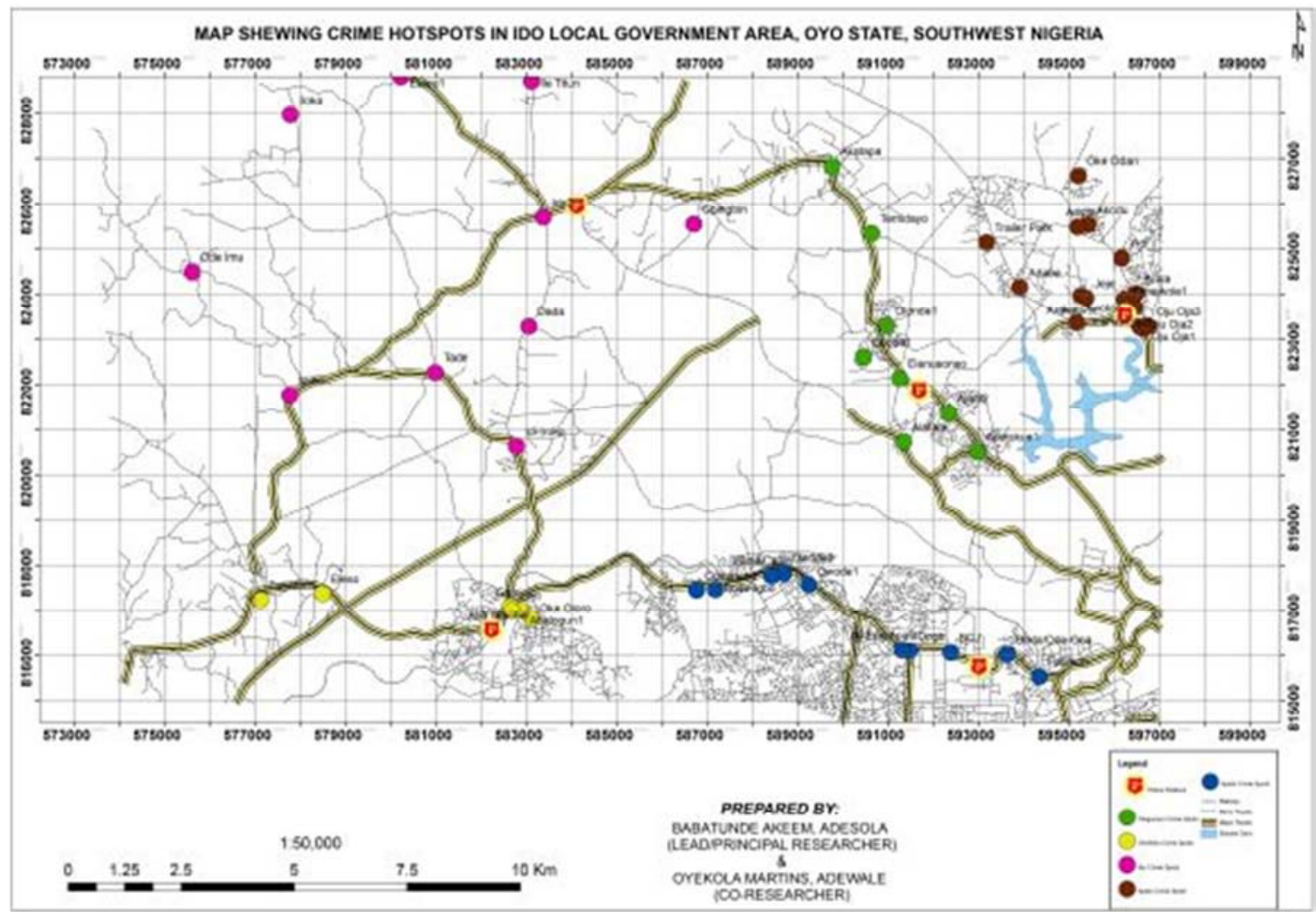

Figure 8. Generalized map showing Crime Hotspots in Ido Local Government Area, Oyo State.

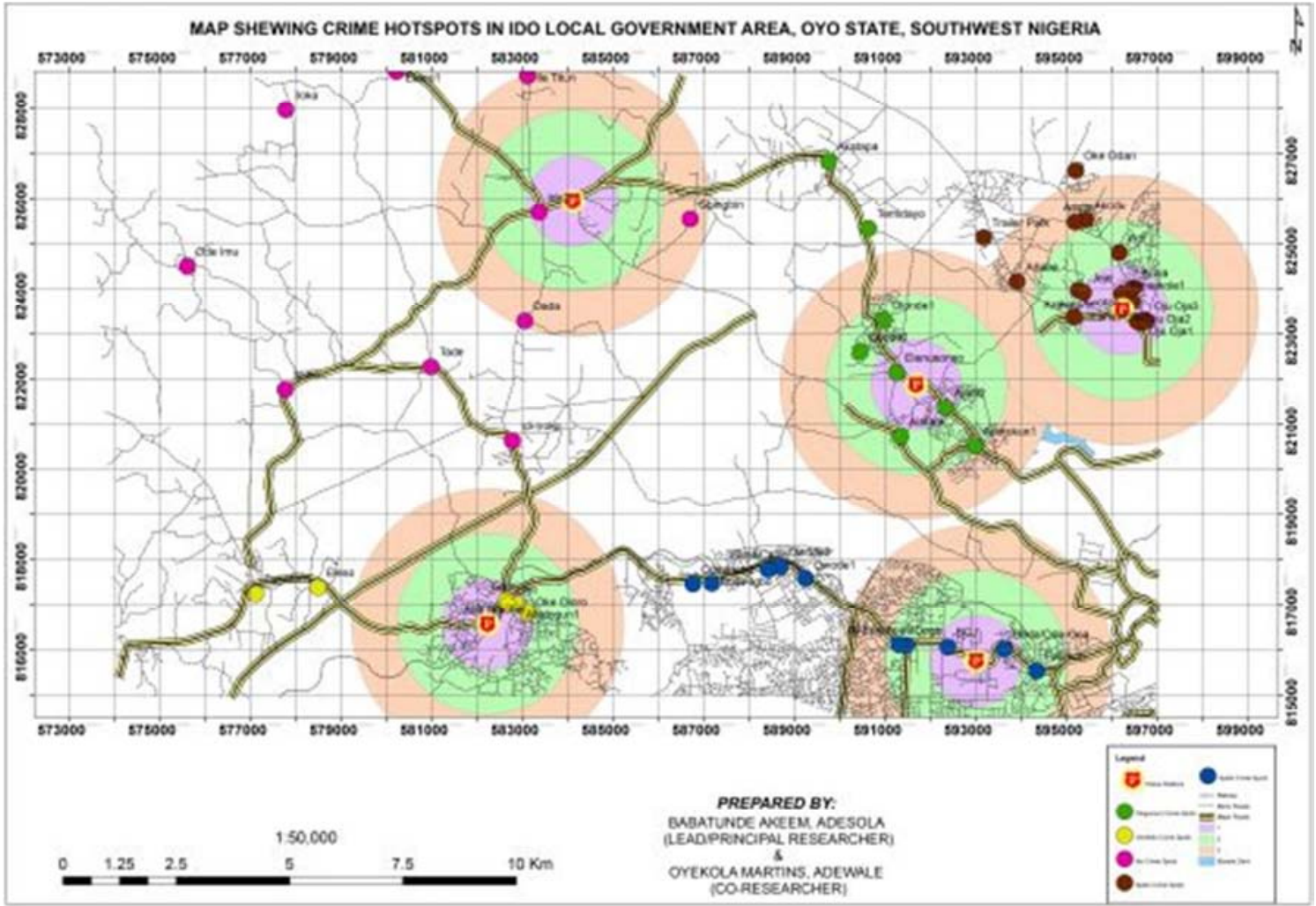

Figure 9. Generalized Map showing $1 \mathrm{~km}, 2 \mathrm{~km}, 3 \mathrm{~km}$ Buffering in Ido Local Government Area. 


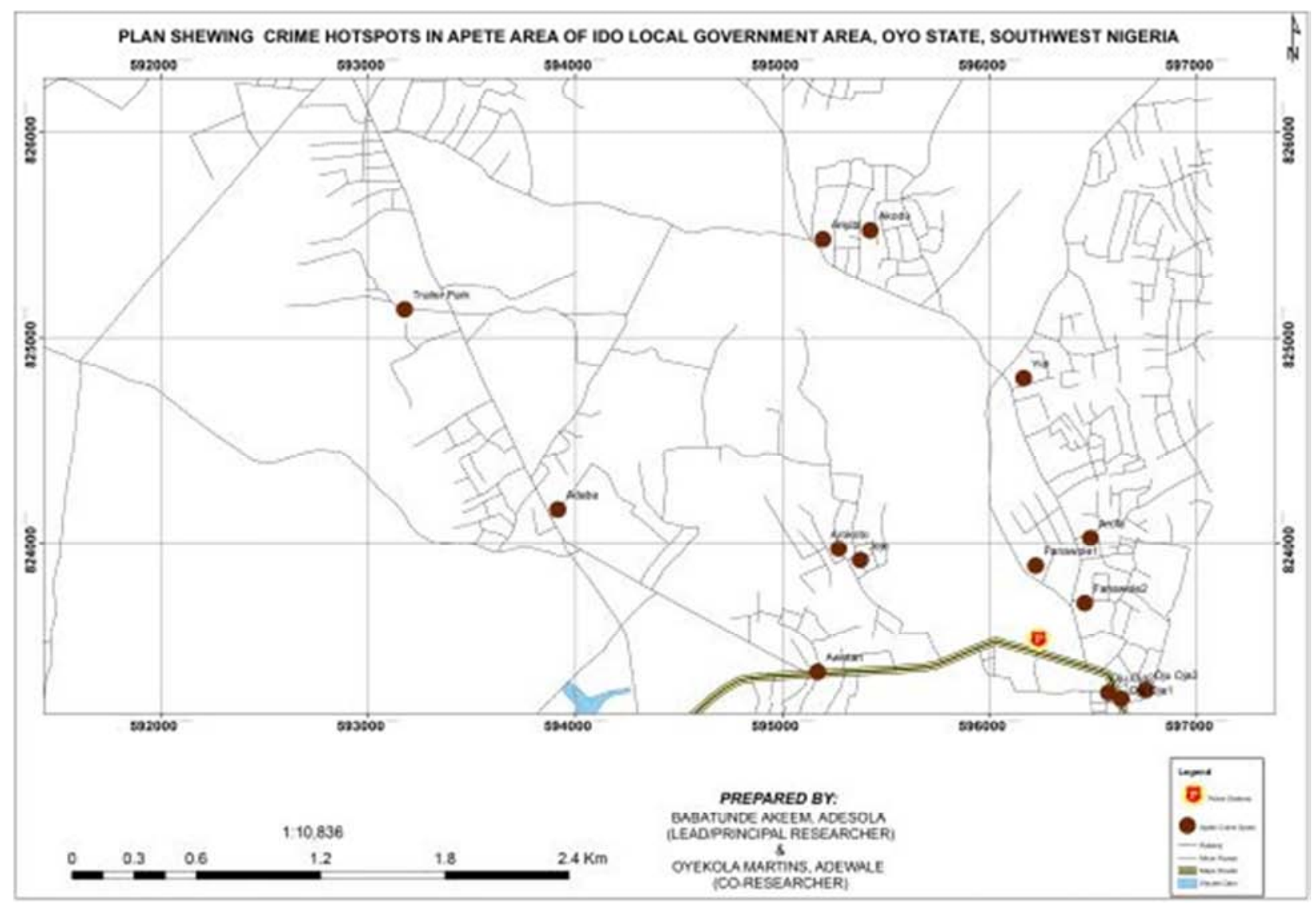

Figure 10. Map showing Crime Hotspots in Apete Area in Ido Local Government Area.

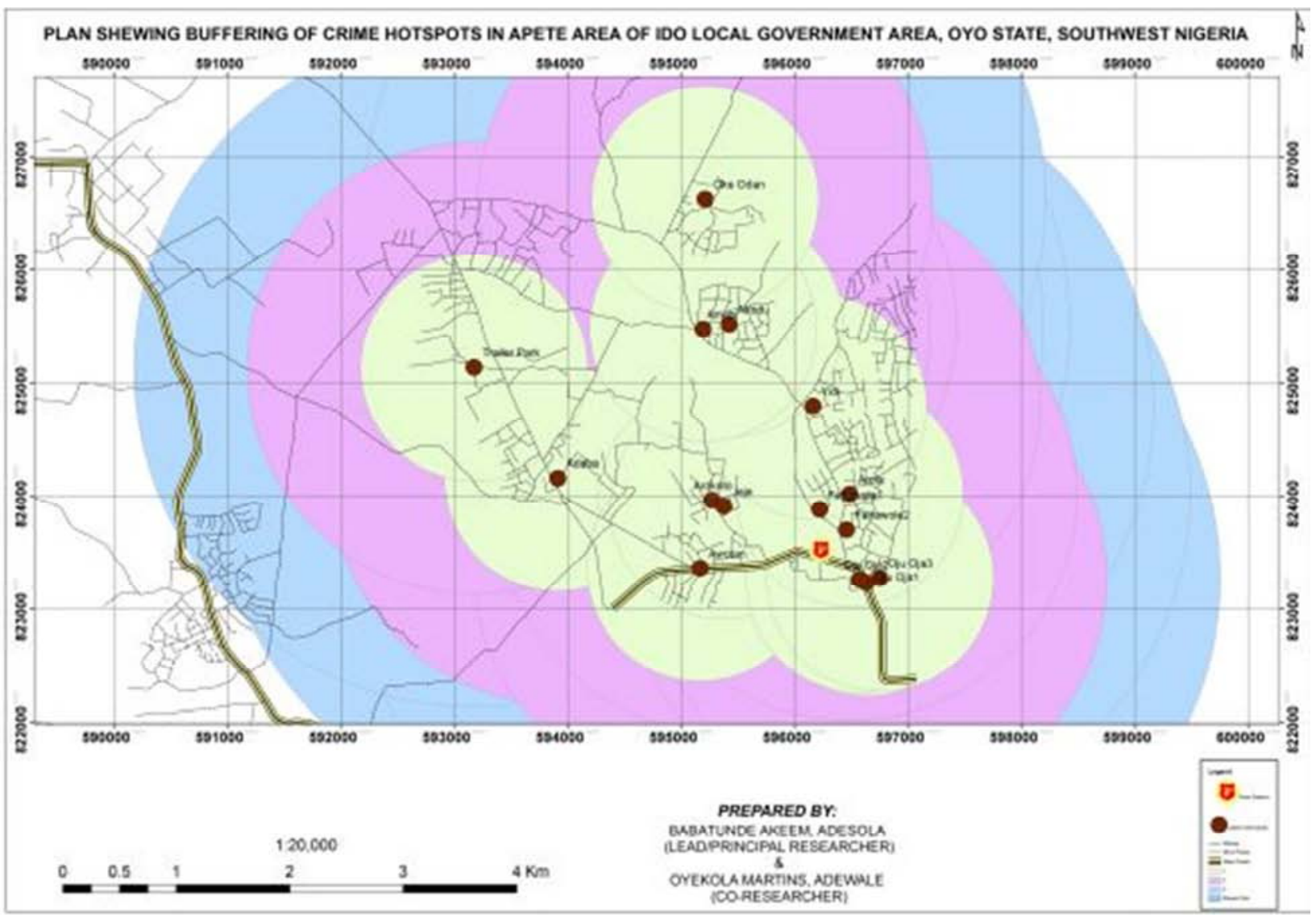

Figure 11. Map showing $1 \mathrm{~km}, 2 \mathrm{~km}, 3 \mathrm{~km}$ Buffering in Apete in Ido Local Government Area. 


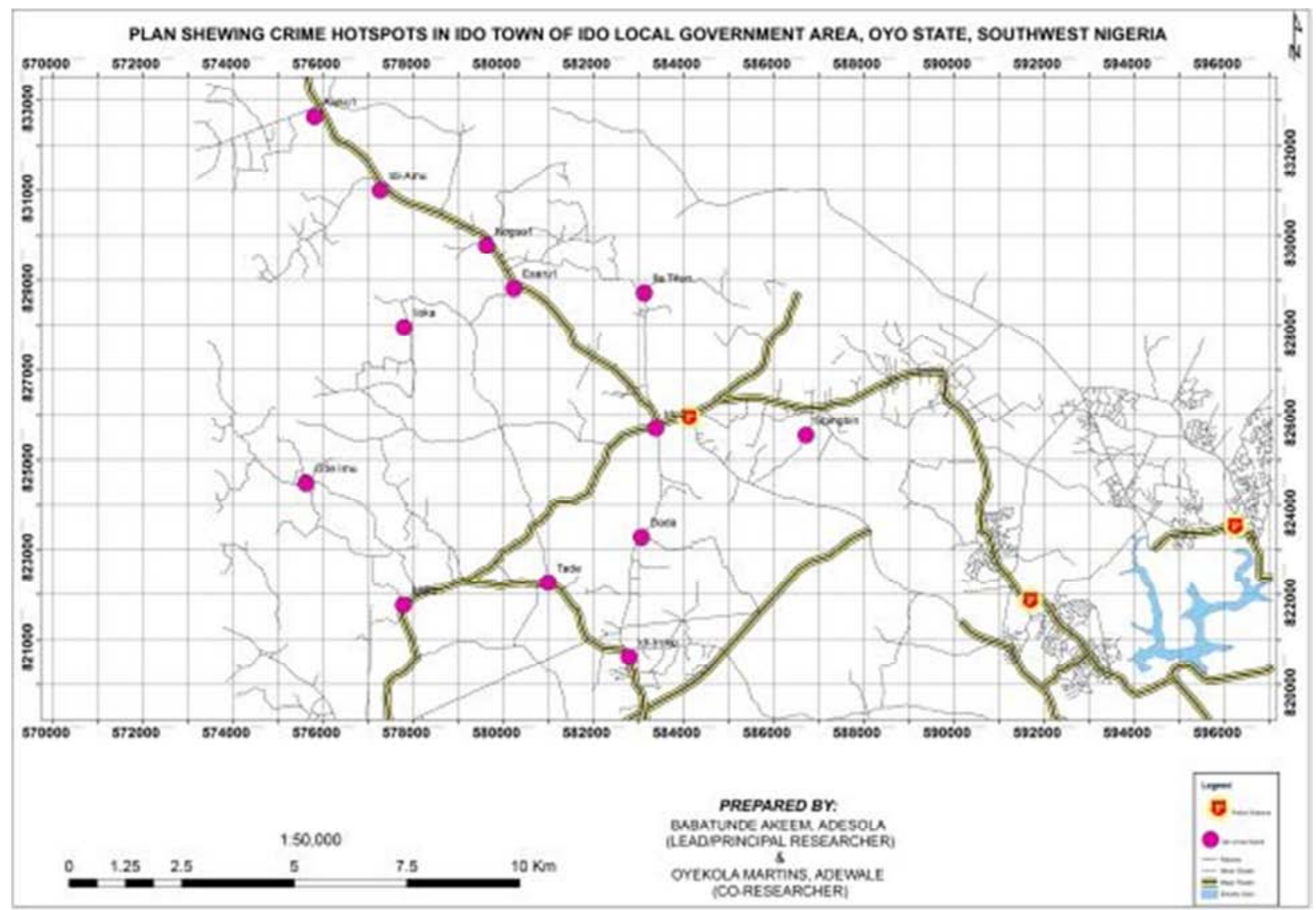

Figure 12. Map showing Crime Hotspots in Ido Area in Ido Local Government Area.

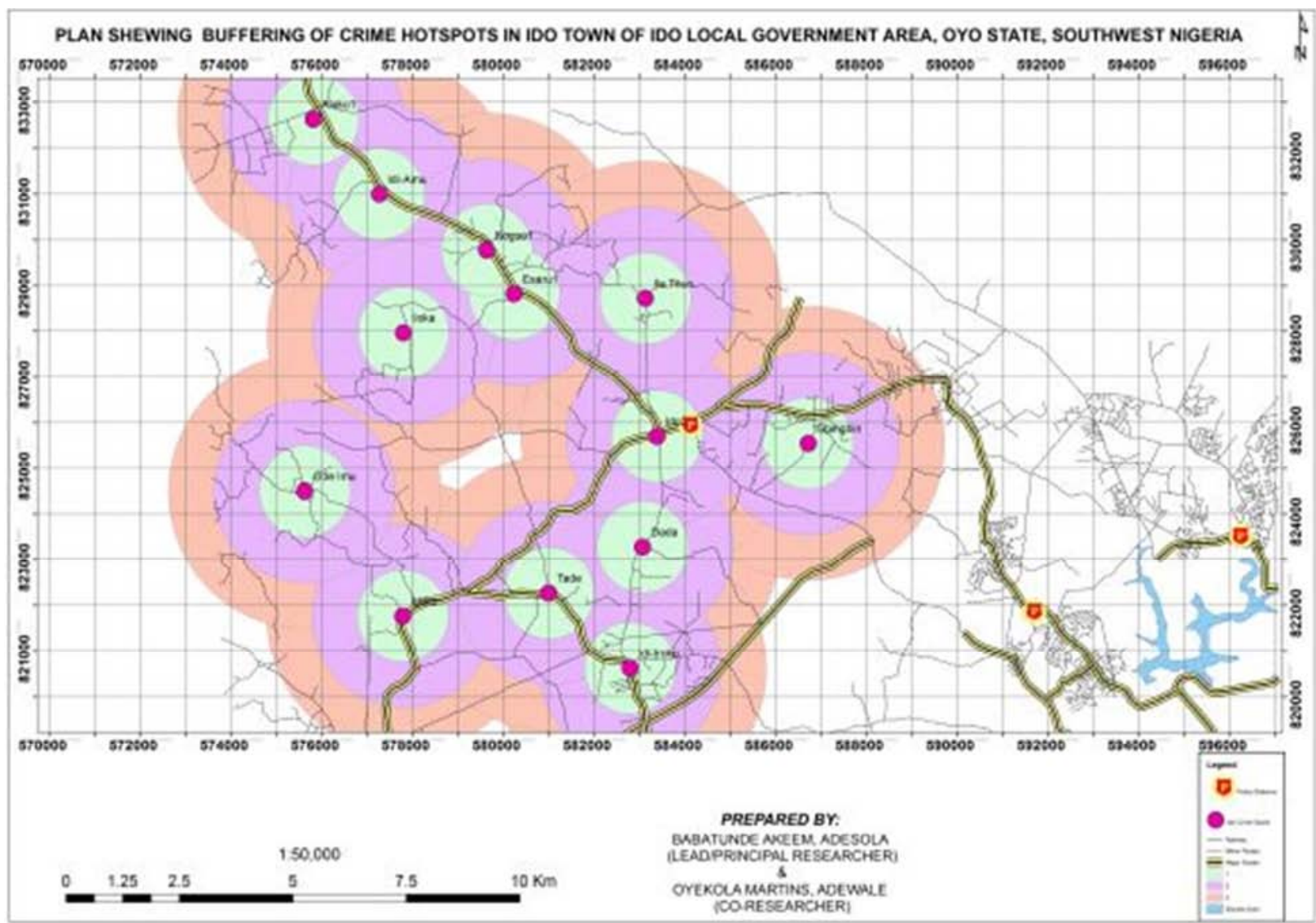

Figure 13. Map showing $1 \mathrm{~km}, 2 \mathrm{~km}, 3 \mathrm{~km}$ Buffering in Ido area in Ido Local Government Area. 


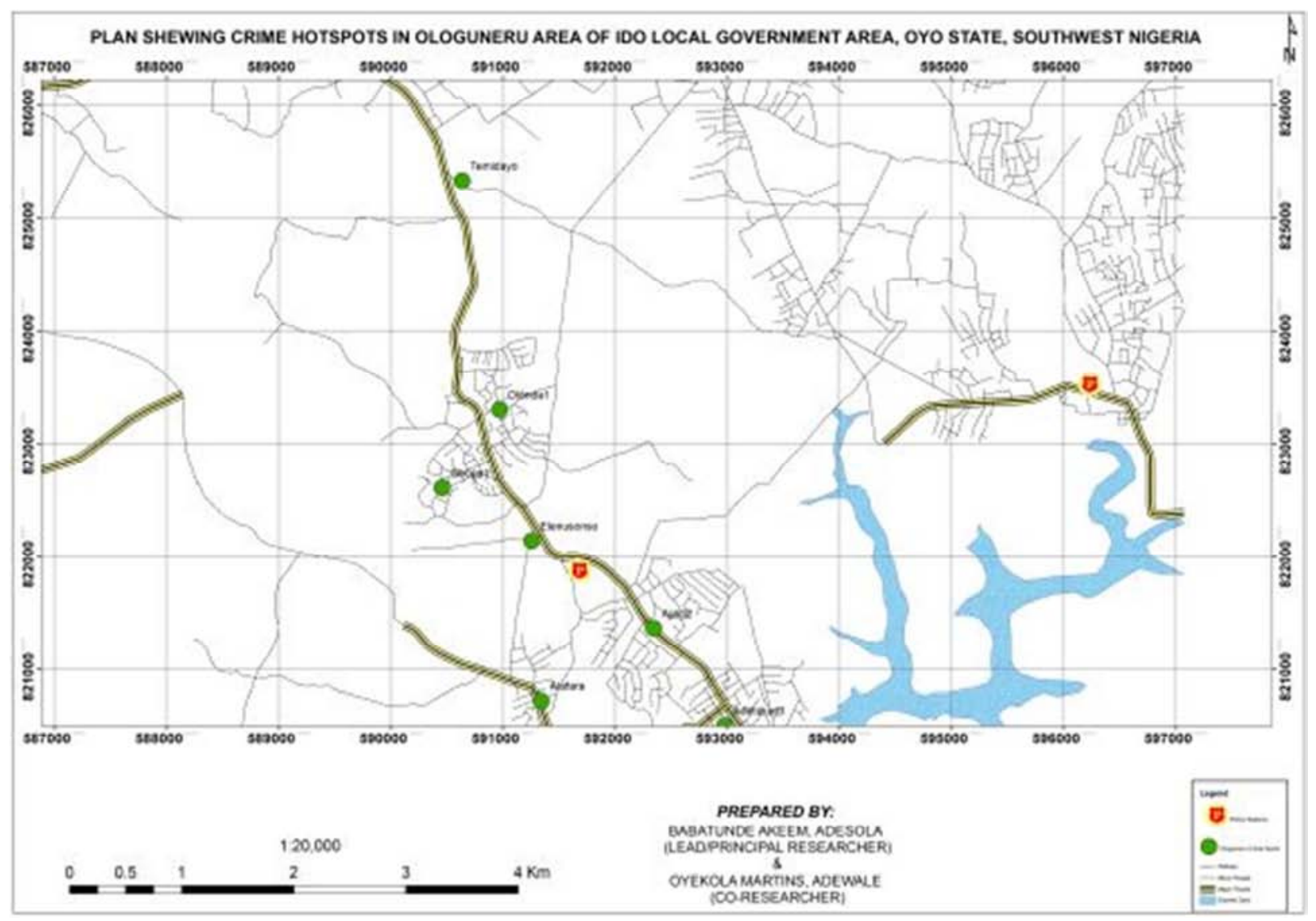

Figure 14. Map showing Crime Hotspots in Ologuneru Area in Ido Local Government Area.

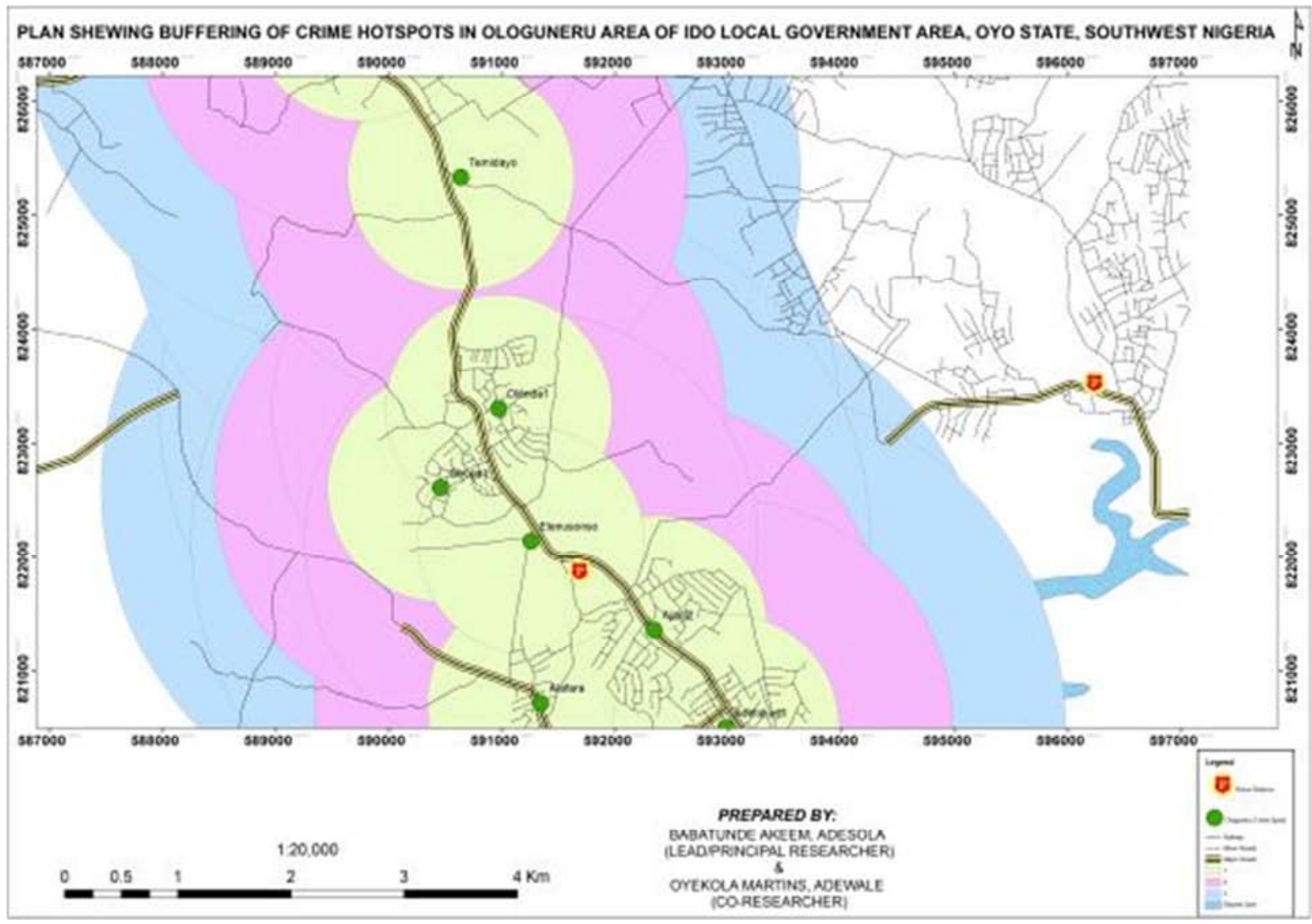

Figure 15. Map showing $1 \mathrm{~km}, 2 \mathrm{~km}, 3 \mathrm{~km}$ Buffering in Ologuneru area in Ido Local Government. 


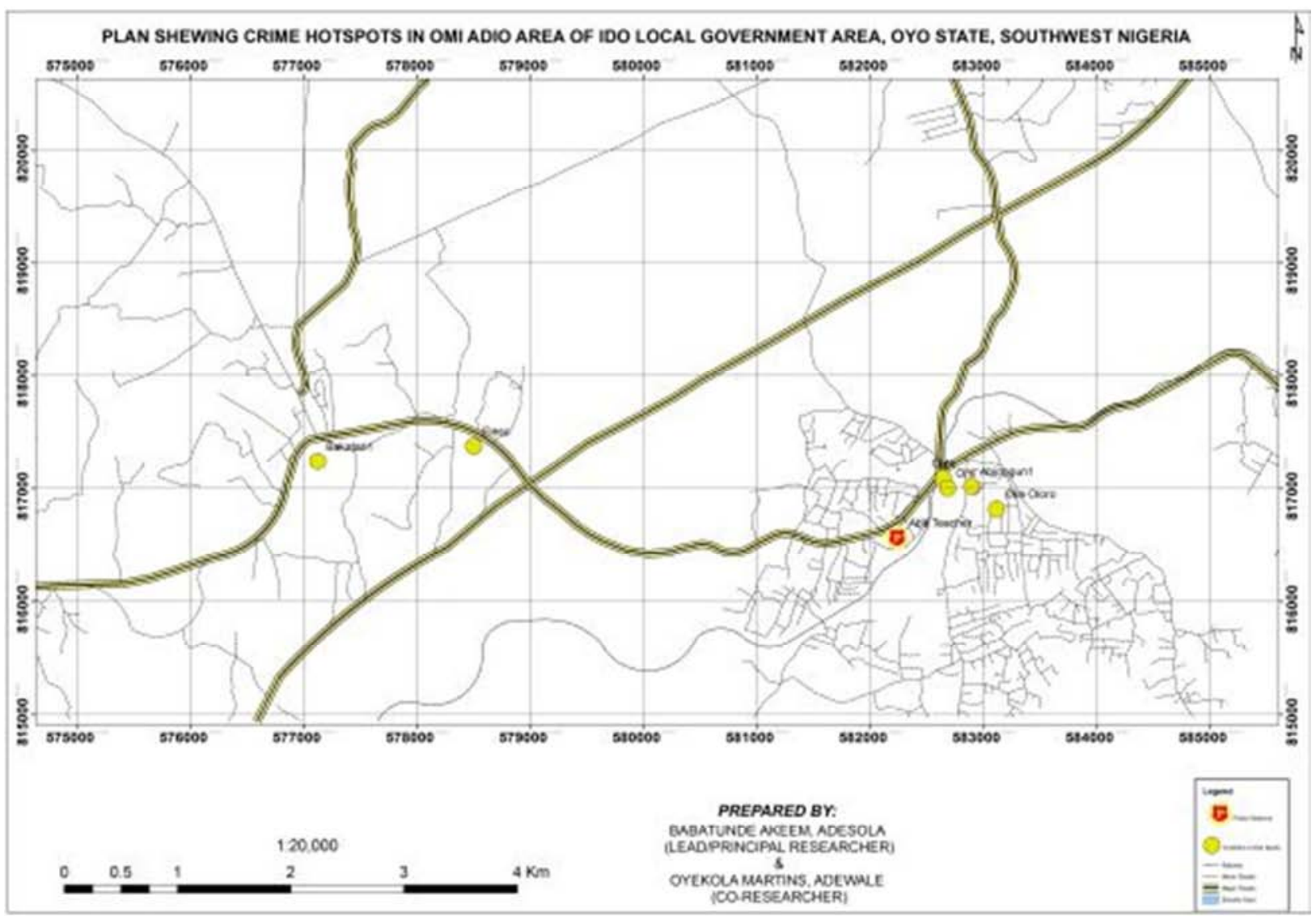

Figure 16. Map showing Crime Hotspots in Omi-Adio Area in Ido Local Government Area.

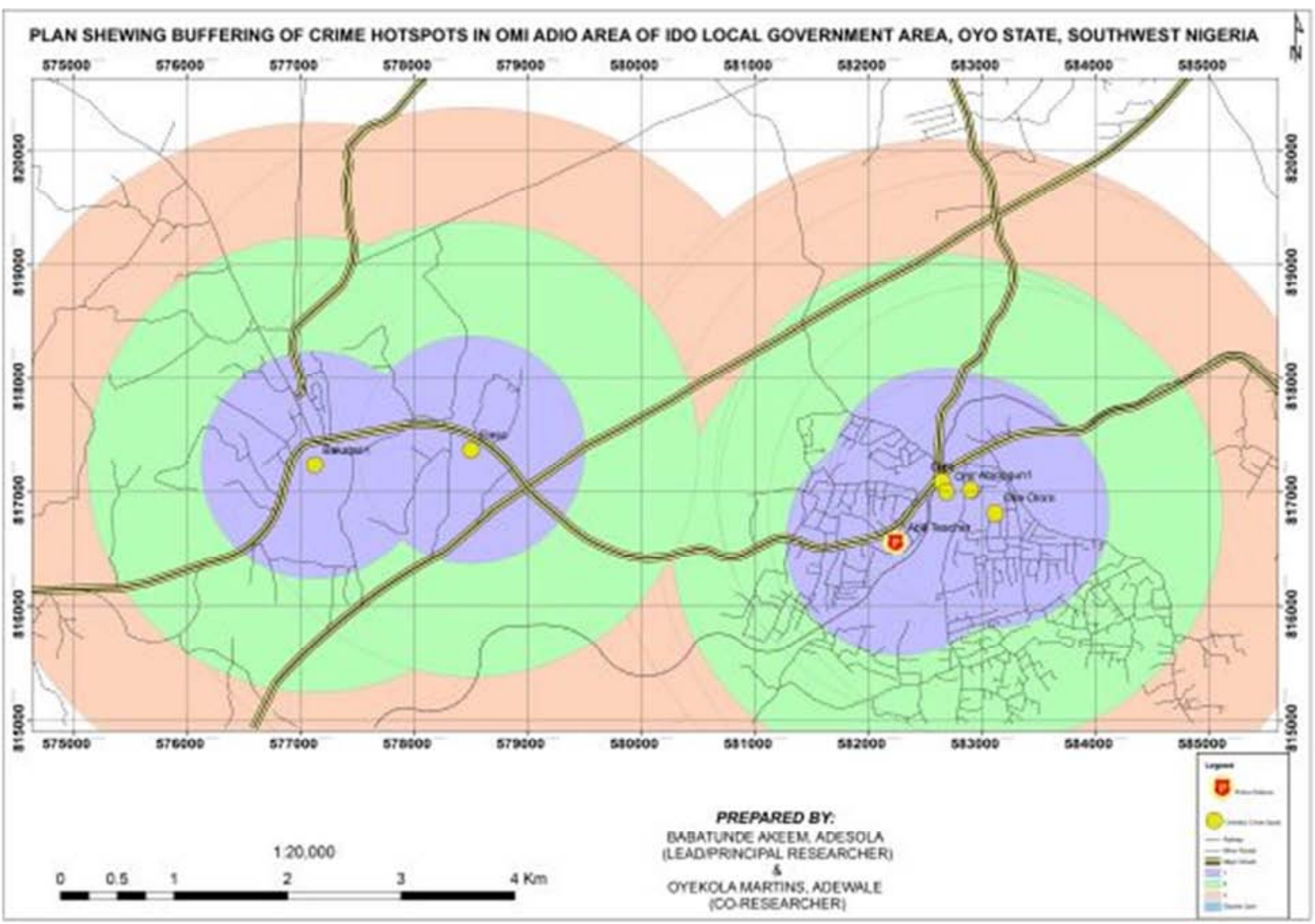

Figure 17. Map showing $1 \mathrm{~km}, 2 \mathrm{~km} 3 \mathrm{~km}$ Buffering in Omi-Adio area in Ido Local Government. 


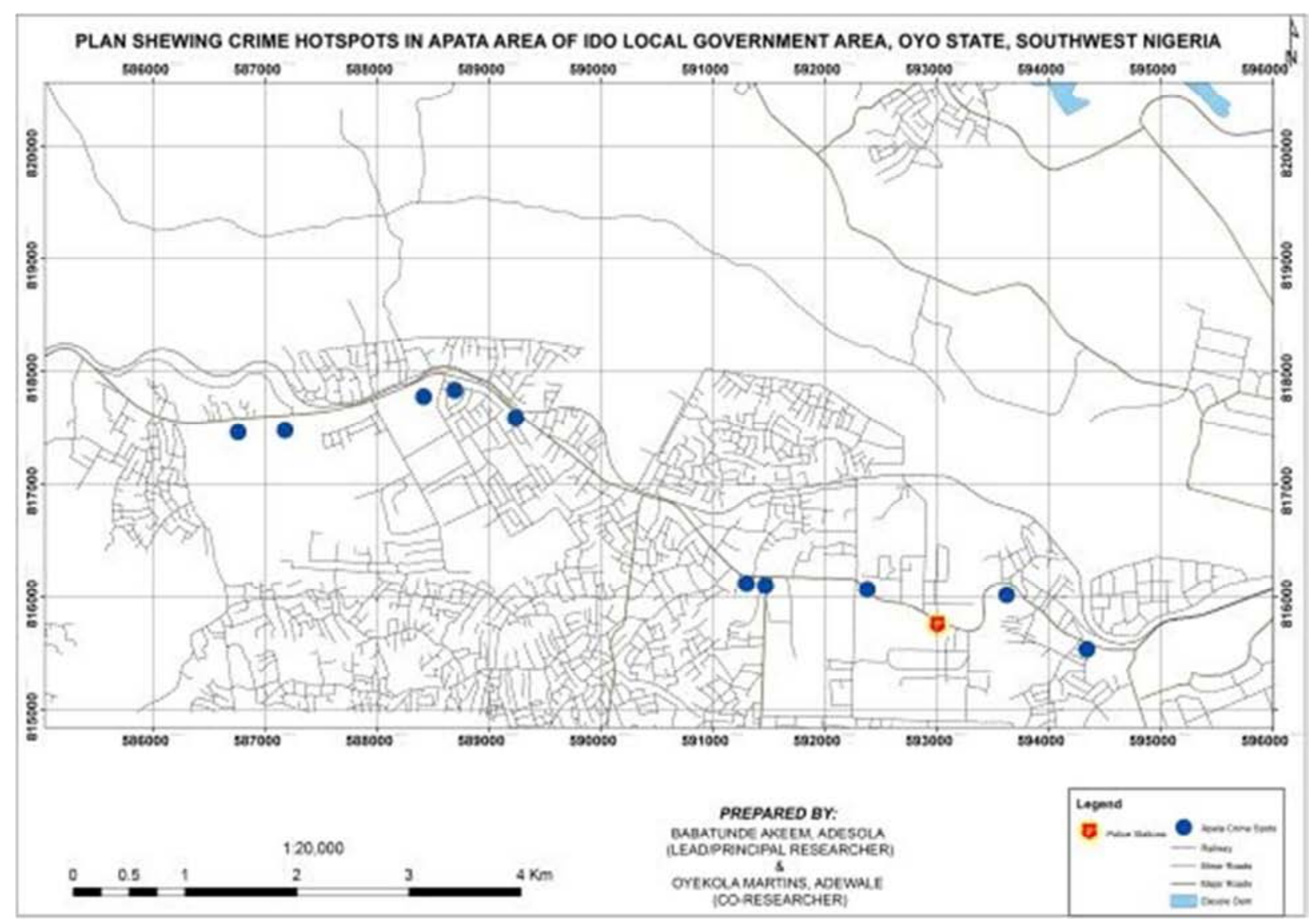

Figure 18. Map showing Crime Hotspots in Apata Area in Ido Local Government Area.

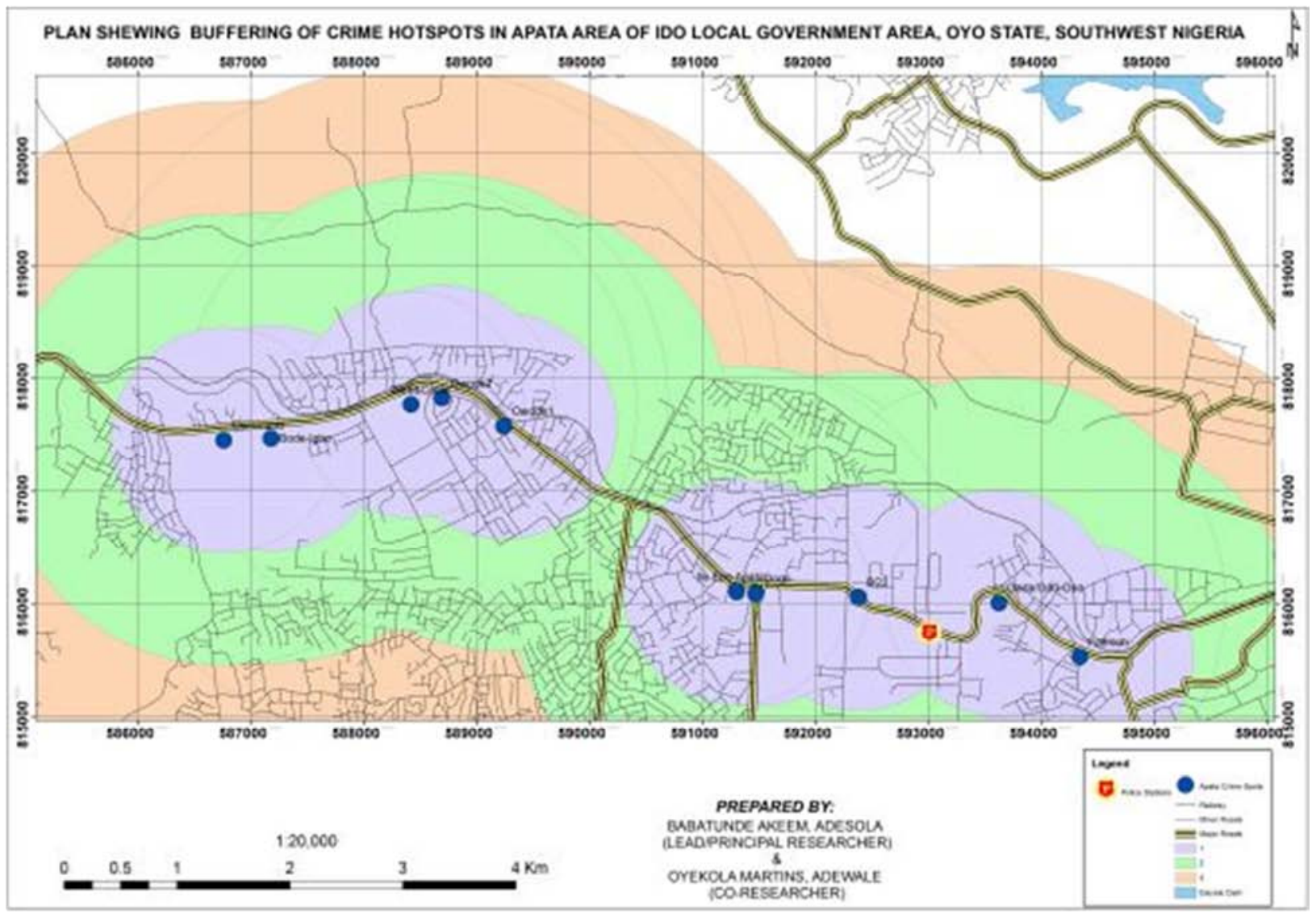

Figure 19. Map showing $1 \mathrm{~km}, 2 \mathrm{~km}, 3 \mathrm{~km}$ Buffering in Apata area in Ido Local Government Area. 
Figure 8 showed all the major crime hotspots in the study area and how closely they are to the police stations. Figures $10,12,14,16$ and 18 showed the individual area where crime hotspots exists from the five major area of the study area. From figures 9, 11, 13, 15, 17, 19 above, $1 \mathrm{~km}, 2 \mathrm{~km}$ and $3 \mathrm{~km}$ buffering analysis was carried out which showed how close and far of the police station to the crime hotspots. In Apete area, it showed that area like trailer park $(3.46 \mathrm{~km})$, Oke-Odan $(3.29 \mathrm{~km})$ are the areas that are too far to the police station while others are close. In Ido area, area like Alako $(10.68 \mathrm{~km})$ Esaru $(4.84 \mathrm{~km})$, Idi-Amu $(8.53 \mathrm{~km})$, Idi-Iroko $(5.48 \mathrm{~km})$, Koguo $(5.91 \mathrm{~km})$, Idiiko $(7.60 \mathrm{~km})$, Tade $(4.83 \mathrm{~km})$, Ode-Inu $(8.64 \mathrm{~km})$, and Iloka $(6.65 \mathrm{~km})$ are those areas that too far from the police while others in Ido area are close but not too close. In Ologuneru area, it showed that only in Temidayo community is very far to the police station while others are close and not too close. In Omi-Adio, area like Bakatari $(5.06 \mathrm{~km})$, and Eleso $(3.71 \mathrm{~km})$ are the area that are far from police station while others are close and not too close. BodeIgbo $(6.08 \mathrm{~km})$, Command $(6.47 \mathrm{~km})$, Owode $1(4.20 \mathrm{~km})$, Owode $2(4.79 \mathrm{~km})$.

\section{Conclusions}

The use geospatial analysis has significance importance in reducing and preventing crime. Most of the police agencies nowadays adopted the use of geographical information system in crime investigations and analysis. The data used in this research is from five divisional police department, field data acquired through surveying methods in Ido local government area of Oyo State, Nigeria. From the finding of this study, the crime data obtained will be depicted on a spatial domain which may be use to show the correlation between each type of crime committed within the five locations studied. Maps produced displayed the locations/hotspots where crimes occurred, and they can be used to help direct police patrols to the places where they are mostly needed. In crime assessment, it showed that there is no direct relationship between crime hotspots and distance to the police stations. Therefore, by increasing the number of police stations and number of police officers/patrol with available facilities required, it is possible to reduce crime rate in the affected areas as well as the study area as a whole. The methodological frame work and the results that was applied in this study presents investigation for crime mapping which have a very promising use in the existing scenario and provides an effective method to law enforcement agencies for crime detection and its prevention within the study area. Hence, the investigations and the results of this study may be used by the law enforcement agencies within the study area for future purposes so as to ensure public safety. Therefore, the security issues in the two areas and in Ido local government area of Oyo State in general requires more attentions by the government, community itself as well as the law enforcement agencies

\section{Recommendations}

i. A system for recording crime data based on locations is recommended.

ii. The use of CCTV and drone should be employed i.e. in monitoring area prone to crime. This will be more effect of cost less.

iii. Community residents should be encouraged to participate in the overall security of their environment.

iv. Police should make fund available as an incentives to those who are ready to vital information crime.

v. Where distances are much, proximity should be enhanced. More police station should be established/created

vi. Government should provide job/employment so that crime could be reduced.

vii. Government should establish a vigilante group that will be helping the police in fighting crime. Also, more patrol vehicles should be given to the police within the study area.

\section{Acknowledgements}

Authors' acknowledged the contribution of Mr. Adewuyi Gbola Kehinde of the department of Surveying and Geoinformatics and the following students; Ajibade Oludare, Morawo Joshua, Ojoawo Johnson, Adeniran Mayowa, Adeeko Isaac, and Ogundepo Toheeb for their assistance during the execution of the research project.

This research was sponsored by Tertiary Education Trust Fund (TETFUND). Address: TETFUND Building: No 6 Zambezi Crescent, Off Aguiyi Ironsi Street, Maitama, Abuja, FCT Nigeria.

\section{References}

[1] Brantingham, P. J. and P. L. Brantingham (eds.) (1991). Environmental Criminology. Prospect Heights, IL: Waveland Press.

[2] Tenibiaje, D. J. (2010). Personality and development of crime in Nigeria. Current Research Journal of Social Sciences, 2 (4), 214-219.

[3] Louis, S., Cookie, W. S., Louis, A. Z. and Sheldon, R. E. (1981). Human Response to Social Problems. The Dorsey Press, Illinois.

[4] Usman, U., Yakubu, M., and Bello, A. Z. (2012). An investigation on the rate of crime in Sokoto state using principal component analysis. Nigerian Journal of Basic and Applied Science, 20 (2), 152-160.

[5] Habibullah, M. S., Baharom, A. H., and Tan, K. S. (2013). Crime and police personnel in Malaysia: An empirical investigation. Prosiding Persidangan Kebangsaan Ekonomi Malaysia Ke VIII (2013). 
[6] Kien, L. H. (2015). The impacts of street crime to commercial real estate in Johor Bahru city centre (JBCC) case study: Jalan Wong Ah Fook and Jalan Trus. Unpublish undergraduate project dissertation submitted to the Department of Real Estate Management, Faculty of Technology Management and Business, Universiti Tun Hussein Onn Malaysia (UTHM).

[7] Sewuese, C. (2014). Spatial pattern of urban crime in Makurdi, Benue State, Nigeria. Un-publish undergraduate a project dissertation submitted to the Department of Urban and Regional Planning. Bauchi: Faculty of Environmental Technology, Abubakar Tafawa Balewa University.

[8] Ajaegbu, O. O. (2012). Rising youth unemployment and violent crime in Nigeria. American Journal of Social Issues Humanities, 2 (5), 315-321.

[9] Amin, M. B., Rahim, M. K., and Ayu, G. M. S. (2014). A trend analysis of violent crimes in Malaysia. Health and the Environment Journal, 5 (2), 41-56.
[10] Dambazau, A. B. (2007a). Criminology justice (Second Ed.) Ibadan: Spectrum Books Limited.

[11] Dambazau, A. B. (2007b). The Nigerian police and crime prevention: Criminology and criminal justice Nigerian, 5 Kaduna. Ch: Defence Academy Press, 221.

[12] Okafor, E. E. (2011). Youth unemployment and implications for stability of democracy in Nigeria. Journal of Sustainable Development in Africa, 13 (1), 1520-5509.

[13] Soh, M. B. C. (2012). Crime and urbanization: Revisited Malaysian case. Procedia - Social and Behavioral Sciences, 42, 291-299.

[14] Katsina, A. M. (2013). Trend analysis of poverty and urban crime in Nigeria since 1999. International Journal of Arts and Commerce, 1 (2).

[15] National population census (2006). 